\title{
ELEKTRONICKÝ PODPIS A MOŽNOSTI JEHO VYUŽITIA - FAKTORY VPLÝVAJÚCE NA JEHO VYUŽÍVANIE
}

\author{
Juraj Fabuš*
}

\section{Úvod}

Séria článkov vzniká za účelom analýzy využívania elektronického podpisu v Slovenskej republike. Hlavnou témou tohto článku je definovanie pojmov a identifikácia faktorov vplývajúcich na využívanie elektronického podpisu v Slovenskej republike. Jedná sa o prvý článok série.

Zverejnenie práce bolo z dôvodu obšírnosti problematiky rozdelené do viacerých článkov, ktoré budú postupne publikované v tomto elektronickom časopise. V nasledujúcich častiach bude popísaná analýza využívania elektronického podpisu v Slovenskej republike, ako aj identifikácia perspektívnych oblastí jeho využívania.

Ciel'om je zvýšit' povedomie o elektronickom podpise, zvýšit' záujem o jeho využívanie, ako aj opísat' okolnosti potrebné pre zavedenie elektronických volieb. Články sú určené všetkým, ktorí elektronický podpis už využívajú, ale aj pre tých, ktorí sa s ním ešte len zoznamujú.

\section{Elektronický podpis}

V elektronickom svete si môžeme vytvorit' neobmedzene vel'a identických kópií a zadarmo. Na druhej strane však elektronické dokumenty umožňujú jednoducho a nebadane povkladat' rôzne zmeny slov a číselných hodnôt do elektronických kópií dokumentov, čo pri rozsiahlych dokumentov býva prehliadnuté. Tieto obavy z používania elektronických dokumentov je možné elegantne vyriešit' uzamknutím pomocou elektronického podpisu. [1]

Pod pojmom elektronický dokument chápeme prostriedok sociálnej komunikácie, ktorý sa od tradičných typov dokumentov (písomných, obrazových, zvukových) odlišuje nie obsahovými, ale formálnymi charakteristikami, najmä digitálnym spôsobom záznamu informácií a z neho vyplývajúcou väčšou nezávislost'ou obsahu dokumentu od materiálneho nosiča (počítačové pamätové médium). Znamená to teda, že všetky tradičné formy dokumentov, ktoré súčasná dokumentológia pozná (monografie, odborné časopisy, noviny, zvukový záznam), môžu existovat' aj vo forme elektronickej. [2]

\footnotetext{
* Ing. Juraj Fabuš, PhD., Žilinská univerzita v Žiline, Fakulta prevádzky a ekonomiky dopravy a spojov, Katedra Spojov, Univerzitná 1, 01026 Žilina, Slovenská republika, tel.: +421 908171 890, E-mail:

juraj.fabus@fpedas.uniza.sk
} 
Elektronický dokument je teda digitálny dokument uchovávaný na fyzickom nosiči, prenášaný alebo spracúvaný pomocou technických prostriedkov v elektrickej, magnetickej, optickej, alebo inej forme. [3]

Elektronický podpis je informácia pripojená alebo inak logicky spojená s elektronickým dokumentom, ktorá musí spĺn̆at’ tieto požiadavky:

a. nemožno ju efektívne vyhotovit' bez znalosti súkromného kl'úča a elektronického dokumentu,

b. na základe znalosti tejto informácie a verejného kl'úča patriaceho k súkromnému kl'úču použitému pri jej vyhotovení možno overit', že elektronický dokument, ku ktorému je pripojená, alebo s ním inak logicky spojená, je zhodný s elektronickým dokumentom použitým na jej vyhotovenie,

c. obsahuje údaj, ktorý identifikuje podpisovatel'a. [3]

Pre zaručený elektronický podpis zákon požaduje splnenie všetkých náležitosti uvedených pre elektronický podpis. Taktiež musí byt' vyhotovený pomocou súkromného kl'úča, ktorý je určený na vyhotovenie zaručeného elektronického podpisu. Môžeme ho vyhotovit' len s použitím bezpečnostného zariadenia na vyhotovenie elektronického podpisu. Spôsob jeho vyhotovenia umožňuje spol'ahlivo určit', ktorá fyzická osoba zaručený elektronický podpis vyhotovila. Zaručený elektronický podpis je platný ak:

- existuje kvalifikovaný certifikát verejného kl'úča patriaceho k súkromnému klúču použitému pri vyhotovení daného elektronického podpisu,

- je preukázatel'né, že kvalifikovaný certifikát bol platný v čase vyhotovenia daného elektronického podpisu,

- elektronický dokument, ku ktorému je zaručený elektronický podpis pripojený alebo s ním inak logicky spojený, je zhodný s dokumentom použitým na jeho vyhotovenie, čo sa overilo použitím verejného kl’úča uvedeného v kvalifikovanom certifikáte. [3]

Elektronický podpis je technicky založený na využití dvojice kl’účov (súkromný a verejný) pre asymetrické šifrovanie správy. Medzi súkromným a verejným kl'účom je matematický vzt'ah a platí, že z verejného kl'úča nie je možné dostupnými technickými prostriedkami odvodit' kl'úč súkromný. Verejný kl'úč preto môžeme publikovat' bez nebezpečenstva prezradenia súkromného kl'úča. Elektronicky podpísanú správu môže čítat' každý, ale je isté, že ju vytvoril práve odosielatel' a že nebola po ceste zmenená. K podpísanej správe sa pripojí kontrolný súčet, tzv. message digest, zašifrovaný súkromným kl'účom odosielatel'a. Príjemca ho pomocou verejného klúča dekóduje a porovná ho s vypočítaným kontrolným súčtom. Ak sa zhodujú, správu odoslal majitel' súkromného kl'úča a po ceste nebola zmenená.

Ak má každá strana komunikácie svoju dvojicu kl'účov, môže odosielatel' správu zašifrovat' (verejným kl'účom príjemcu), aj digitálne podpísat' (svojim súkromným kl’účom), čím je táto správa dokonale chránená (lepšie ako klasické dokumenty bez ochrany proti zmene). Príjemca má zaručené, že:

- správu si po ceste nikto tretí neprečítal (šifrovanie),

- správu odoslal skutočne ten, kto je podpísaný (podpis),

- správa nebola po ceste zmenená (digest) . [4] 


\section{Využitie elektronického podpisu}

Potreba vzniku elektronického podpisu vyplynula $\mathrm{z}$ postupnej elektronizácie spoločnosti, ked' vel'ké množstvo agendy firiem, štátnej a verejnej správy sa postupne presúva do elektronickej podoby. Elektronický podpis v súčasnosti pokrýva rôzne bezpečnostné požiadavky, medzi ktoré patrí autentifikácia, integrita údajov, sledovatel'nost'.

Najväčší a nezastupitel'ný význam elektronického podpisu spočíva v nepopieratel'nosti, náhrade vlastnoručného podpisu v elektronickom styku. Ak používatel' vytvorí elektronický podpis dokumentu, nemôže v budúcnosti popriet', že to vytvoril on. Na dosiahnutie nepopieratel'nosti treba dodržat' d'alšie podmienky. Základnou je, aby jediným vlastníkom certifikátu a príslušného podpisovacieho kl'úča bol určitý konkrétny použivatel'. Potom možno dosiahnut' nepopieratel'nost' pôvodu vytvorenia. Ak elektronický podpis obsahuje aj časovú pečiatku, možno dosiahnut' aj nepopieratel'nost' času vytvorenia. S týmito dvoma atribútmi vieme, ak si budeme bezpečne uchovávat' všetky elektronické podpisy, kto vykonal danú akciu a kedy. Tieto dva atribúty vytvorili $\mathrm{z}$ elektronického podpisu dostatočne silnú technológiu na to, aby sa uvažovalo o náhrade vlastnoručného podpisu elektronickým podpisom. [5]

Elektronický podpis sa využíva najmä v uzatvorených systémoch. Uzatvorený systém môžeme chápat' ako systém, v ktorom sú aktéri (ten, kto podpisuje aj ten, kto overuje) vopred známi. Zvyčajne existuje medzi nimi právny vzt’ah uzatvorený formou zmluvy. Medzi najčastejšie uzatvorené systémy využívajúce elektronický podpis patria e-banking aplikácie, správa a obeh dokumentov $\mathrm{v}$ rámci organizácie, informačné systémy v zdravotníctve.

Zaručený elektronický podpis sa využíva najmä v otvorených systémoch, hoci môže byt' výhodné využitie aj v uzatvorených systémoch. Otvorené systémy zväčša chápeme ako systémy, v ktorom aktéri nie sú vopred známi. Bežným príkladom otvorených systémov sú tie, ktoré zabezpečujú komunikáciu medzi občanmi a štátnou resp. verejnou správou, napr. elektronická podatel'ňa. Zaručený elektronický podpis predstavuje drahšie riešenie, vo všeobecnosti predpokladáme vyššie prvotné aj prevádzkové náklady. Pre klientov môže predstavovat' výhody štandardizovaného riešenia, ktorého úroveň, z pohl'adu bezpečnosti, funkčnosti a d'alších technologických aspektov, je hodnotená nezávisle audítorom a Národným bezpečnostným úradom. [5]

Elektronický podpis sa v dnešnej dobre využíva najmä pri:

- podpisovaní e-mailových správ - v rámci spoločnosti, ale aj správ smerujúcich von z organizácie, prostredníctvom ich šifrovania,

- bezpečnom prihlasovaní sa do systému certifikátom - náhrada za prihlásenie pomocou mena a hesla,

- bezpečnej komunikácií s webovými stránkami

- EDI komunikácii - zavedení elektronickej výmeny dokumentov medzi dvoma subjektmi a tým nahradenie papierovej dokumentácie elektronickou,

- zasielanie výplatných pások elektronicky - k obsahu správy sa dostane len odosielatel' a adresát,

- občiansky elektronický podpis - preukaz má vel'kost' kreditnej karty, v ktorej je umiestnený čip. $\mathrm{K}$ elektronickému občianskemu preukazu, respektíve identifikačnej karte, každý občan dostane aj čítačku.

- zasielanie faktúr elektronicky - v zmysle platnej legislatívy musí byt' faktúra zaručená elektronickým podpisom, pričom sa nevyžaduje zaručený elektronický podpis ale postačujúci je elektronický podpis. [6] 
Zaručený elektronický podpis a s ním súvisiaci kvalifikovaný certifikát možno $\mathrm{v}$ dnešnej dobe použit' pri komunikácii s rôznymi organizáciami. Bližšie sa tejto problematike budem venovat' v nasledujúcom článku zo série.

\section{Faktory podporujúce použitie elektronického podpisu}

Elektronické dáta majú v porovnaní s klasickými papierovými dokumentmi zjavné výhody. Elektronické záznamy môžeme vytvárat' a ukladat' rýchlejšie a efektívnejšie, zaberajú menej fyzického priestoru, jednoduchšie sa triedia a vyhl'adávajú. Faktorov, ovplyvňujúcich podporu použitia elektronického podpisu, môžeme spomenút' hned' niekol'ko:

- Rýchlost' doručenia elektronických dokumentov - Objem elektronickej komunikácie je zatial' malý, analýzy však ukázali, že vybavovanie stránok je rýchlejšie a efektívnejšie. Technológie pomôžu odbremenit' úrady od zdĺhavého osobného kontaktu a postupom času je možné, že rozdelovanie elektronických podaní vytesní i drobné úplatkárstvo.

- Časová flexibilita - Neviazanost' občanov na pracovnú dobu potrebného podniku.

- Miestna flexibilita - Neviazanost' na miesto podpisu.

- Zníženie finančných nákladov - Budúcnost'sa skrýva v štandardizácii a cenovo nenáročnej dostupnosti osobných kl'účov. Znamená to, že vlády musia zaistit' nielen rozšírenie a dostupnost' softvéru, ale i to, aby občan získal podpis za nízky poplatok. Vyžaduje to finančné investície i úsilie. [7]

Brzdiace faktory v značnej miere ovplyvňujú bežného občana a vytvárajú negatívny postoj $\mathrm{k}$ elektronickému podpisu. Uvediem tie $\mathrm{z}$ nich, ktoré najviac spomal'ujú rozvíjanie elektronického podpisu:

1. Psychologické

- konzervatívnost' klientov (l'udia sú obmedzení pri využívaní tejto techniky, pretože sa boja niečoho nového),

- počítačová gramotnost',

- nedôvera vyplývajúca zo zverejnených prípadov zneužitia elektronického bankovníctva.

2. Technické

- nedostupnost' internetu na celom území, v každej lokalite Slovenskej republiky,

- nedostatočná vybavenost' výpočtovou technikou (nie každý občan má možnost', vzhl'adom na finančné prostriedky, disponovat' dostačujúcou výpočtovou technikou),

- nemožnost' okamžitého overenia platnosti zaručeného elektronického podpisu.

3. Legislatívne

- Nedoriešené otázky archivovania a dlhodobého archivovania dokumentov podpísaných elektronickým podpisom a zaručeným elektronickým podpisom.

4. Finančné

- Návratnost' finančných nákladov nie je zatial' vzhl'adom na súčasné možnosti využitia dostatočná. [8] 


\section{Záver}

V dnešnej dobe sa stáva komunikácia základom všetkých činností. Informačné technológie sú významné vo všetkých oblastiach aktuálnej spoločnosti. Prepojenie technológií a komunikácie má spoločný minimálne jeden podstatný faktor a tým je bezpečnost'. Zabezpečenie na vysokej úrovni nám pri komunikácií vie garantovat’ elektronický podpis.

Elektronický podpis a zaručený elektronický podpis sa stáva nevyhnutnou súčast'ou pri elektronickej komunikácii medzi orgánmi štátnej správy a v organizáciách, v ktorých je potrebná ochrana integrity elektronických dokumentov proti falšovaniu a nepopieratel'né preukázanie, že elektronický dokument $\mathrm{v}$ danom čase existoval a jeho obsah bol vytvorený alebo prezentovaný konkrétnou osobou.

\section{Literatúra}

[1] Ing. RYBÁR, P. Základné princípy elektronického podpisu a zaručeneého elektronického podpisu (ZEP). 2009. [online]. Národný bezpečnostný úrad, Bratislava, 2009.

Dostupné na internete: <http://www.nbusr.sk/ipublisher/files/nbusr.sk/elektronickypodpis/legislativa/2-1/el_podpis.pdf $>$.

[2] Elektronický document. [online]. [s.a.]. Dostupné na internete: $<$ http://edi.fmph.uniba.sk/ winczer/SocialneAspekty/SvecElektronickyDokument.pdf $>$.

[3] Zákon č. 215/2002 Z.z. z 15. marca 2002 o elektronickom podpise a o zmene a doplnení niektorých zákonov v znení zákona č. 679/2004 Z.z., zákona č. 25/2006 Z.z., zákona č. 275/2006 Z.z. a zákona č. 214/2008 Z.z..

[4] Ing. Pavel Horovčák, CSc.. Elektronická identifikácia, elektronický podpis a bezpečnost' informačných systémov. In Acta Montanistica Slovaca. [online]. 2002, vol. 7 , no. 4

Dostupné na ineternete: <http://actamont.tuke.sk/pdf/2002/n4/6horovcak.pdf $>$.

[5] IBM Slovensko. Elektronické podpisovanie dokumentov. In eFOCUS. [online]. 2005, no 2.

Dostupné na internete: $<$ http://www.efocus.sk/images/archiv/file_217_0.pdf $>$.

[6] Elektronický podpis. [online]. [s.a.].

Dostupné na internete: $<\mathrm{http}: / / \mathrm{www} .1$ larik.sk/elektronicky-podpis>.

[7] Elektronický podpis - všetko čo by ste mali o ňom vediet'. [online]. [s.a.].

Dostupné na internete: $<$ http://www.itapa.sk/index.php?ID=3068>

[8] Ing. Ivan Mizerák. Súčasné problémy širšieho uplatnenia elektronického podpisu a elektronickej komunikácie na Slovensku. [online]. [s.a.].

Dostupné na internete: <www.saec.sk/images/evpu.ppt>

\section{Grantová podpora}

Článok je súčast'ou riešenia úlohy Data modeling $\mathrm{v}$ procese vzdelávania $\mathrm{v}$ počítačovom laboratóriu Katedry spojov - KEGA 036-017ŽU-4/2010 a Integrácia študentov so zdravotným postihom do edukačného procesu s dôrazom na unifikáciu prístupu $\mathrm{k}$ virtuálnej informačnej infraštruktúre a prostriedkom IKT - KEGA 386-017SPU-4/2010. 